\title{
RADIOLARIAN ROCKS OF THE CULM MEASURES, DEVONSHIRE.
}

SIn,-I wish to call attention to the unfortunate mistake which I have made on pp. 4, 105, 106, 107, 108, and 109 of the Geological Survey Memoir on Plymouth and Liskeard, 1907, in attributing to Mr. Fox alone various statements which I have quoted from the joint papers of Messrs. Hinde and Fox on the Radiolarian rocks of the Culm Measures, in the Quart. Journ. Geol. Soc, vol. li, 1895, and in the Transactions of the Devonshire Association, vol. xxviii, 1896, and in Proc. Geologists' Association, vol. $\mathrm{xx}$, pp. 88, 92, 1907. I desire to express my regret, and to offer my apologies to these authors for the unintentionally deficient references to their joint papers.

28, JERMYN STREET, S.W.

February 12th, 1908 .

W. A. E. UssHer.

\section{THE IIQUID AND PNEUMATOLYTIC THFORIES OF GRANITIC} MINERALS.

SIR, - I have noticed with much regret that the conclusions arrived at by the Geological Survey ${ }^{1}$ as to the crystallisation of the West Country Granites are in hopeless conflict with several communications which the Geological Magazine has honoured me by publishing.

Broadly speaking, the Survey authorities have adopted the high temperature gaseous theory, ${ }^{*}$ whereas I have assumed the impregnability of the low-temperature liquid theory. Any attempt at reconciliation is useless, but it may be as well if I submit the list of the authorities on which I have relied. They aro in order of date as follows:-

(1) Sorby, "Microscopical Structure of Crystals": Q.J.G.S., 1858.

(2) Sorby \& Butler, "Rubies, Sapphires, and Diamonds": Proc. R.S., 1869.

(3) Hartley, "The Identification of Liquid Carbonic Acid in Mineral Cavities": Royal Micro. Soc., March 1st, 1876.

(4) Sorby, "On the Critical Point in the Consolidation of Granitic Rocks": Mineralogical Mag., September 6th, 1876.

(5) Hartley, "On Variations in the Critical Point of Carbon Dioxide in Minerals," etc.: Journ. Chem. Soc., September, 1876.

(6) Hartley, "Observations on Fluid Cavities": Journ. Chem. Soc, March, 1877.

(7) Hartley, "Attraction and Repulsion of Bubbles by Heat": Proc. R.S., $187 \%$.

(8) Hartley, "On the Constant Vibration of Minute Bubbles": Proc. R.S., 1877.

(9) Report on the Conditions under which Liquid Carbonic Acid exists in Rocks and Minerals, by a Committee consisting of Walter Noel Hartley, F.R.S.E., E. J. Mills, D.Sc., F.R.S., and W. Chandler Roberts, F.R.S. Drawn up by W. N. Hartley, F.R.S.E.: Rep. Brit. Assoc., 1877.

(10) A. Daubrée, "E'tudes Synthćtiques de Géologie Expérimentale": 1879.

(11) Sorby: Address to the Geological Section of the British Association, 1880.

(12) Fouqué et Lévy, "Synthèse des Minéraux et des Roches": 1883.

I am bound to admit that the first chapter of Daubrée's "Experimental Geology" justifies the views of the Geological Surveyors, and

I “ Land's End District," pp. 49-60, 1907.

2 " "Pneumatolysis' reters to the action of gases above critical temperature" ("Falmouth and Camborne," p. 168, 1906). 
that Fouqué \& Lévy do not directly challenge them. It will, however, be noticed that the papers of Dr. Sorby and Professor Hartley, published as they are in the records of Societies such as the Royal, Chemical, Microscopical, and Mineralogical, and in the Reports of the British Association (and published, moreover, quite independently, and for different objects of research), might very well not have all come under the notice of M.M. Daubrée, Fouqué, and Léry; and that indeed seems to have been the case.

Speaking for myself, I certainly should not have seen most of the abore papers had not the authors most generously sent me reprints.

I am certainly in a great difficulty. One of the minerals relied on by the Geological Surves to prove pneumatolytic action at temperatures above the critical temperature of water is topaz. But, in Professor Hartley's paper on Fluid Carities to the Chemical Society in 1877, one section is entitled "On the Probable Temperature incident to the formation of Topaz," and one conclusion arrired at is that topaz sometimes crystallises under and sometimes orer the C.T. of water.

The petrologists dismiss all the evidence relied on by the chemists for ascertaining the temperatures of rock-formation. But there is this fact to be borne in mind, that while the chemists have minutely studied separate minerals, the petrologists have taken a wider view of rocks and magmas.

The following example will serve to show how widely eminent petrologists and chemists differ as to probable temperatures. Professor Hartley, in discussing the formation of negatire cavities in quartz, observes:- "The mineral is crystallised at a high temperature, say $150^{\circ}$ C." (on Fluid Cavities). " The theory adopted by the Geological Surveyors often necessitates a temperature exceeding $365^{\circ} \mathrm{C}$.

Since the publication of the Cornish Memoirs I have for the first time understood the irritation that my unfortunate little papers have naturally caused. St. Paul hits the position off exactly : "If I know not the meaning of the voice, I shall be unto him that speaketh a barbarian ; and he that speaketh shall be a barbarian unto me."

I can assure my geological friends that for very many reasons I most deeply regret ever having published outside the provinces anything on the subjects of either Petrology or Ripplemark; as both subjects have led to a vast amount of genuine misunderstanding and discomfort, and I may add of mystification; and they are not worth it.

A. R. Huvr.

\section{ORIGIN OF THE SUDBURY NICKEL ORES.}

Srk,-In Professor Coleman's interesting restatement of what he regards as "incontrovertible proof" of the igneous origin of the Sulbury nickel ores, he makes the safe assumption that I had not seen the long announced second part of his monograph (Report of the Bureau of Mines, Ontario, vol. xiv, No. 3). It would be inexcusable for anyone to discuss the Sudbury mining field without

1 Reprint, p. 8. 